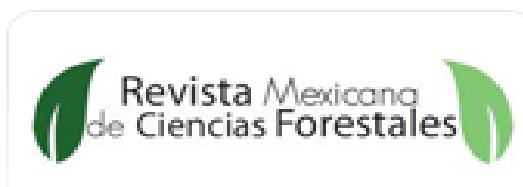

\section{Revista Mexicana de Ciencias Forestales}

ISSN: 2007-1132

ciencia.forestal2@inifap.gob.mx

Instituto Nacional de Investigaciones

Forestales, Agrícolas y Pecuarias

México

Muñoz Flores, H. Jesús; Sáenz Reyes, J. Trinidad; García Sánchez, J. Jesús; Hernández Máximo, Edgar; Anguiano Contrera, José ÁREAS POTENCIALES PARA ESTABLECER PLANTACIONES FORESTALES COMERCIALES DE Pinus pseudostrobus Lindl.Y Pinus greggii Engelm. EN MICHOACÁN

Revista Mexicana de Ciencias Forestales, vol. 2, núm. 5, mayo-junio, 2011, pp. 29-44 Instituto Nacional de Investigaciones Forestales, Agrícolas y Pecuarias

Distrito Federal, México

Disponible en: http://www.redalyc.org/articulo.oa?id=63438960004

Cómo citar el artículo

- Número completo

- Más información del artículo

- Página de la revista en redalyc.org

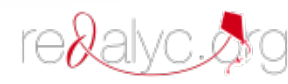

Sistema de Información Científica

Red de Revistas Científicas de América Latina, el Caribe, España y Portugal Proyecto académico sin fines de lucro, desarrollado bajo la iniciativa de acceso abierto 


\title{
ÁREAS POTENCIALES PARA ESTABLECER PLANTACIONES FORESTALES COMERCIALES DE Pinus pseudostrobus Lindl. Y Pinus greggii Engelm. EN MICHOACÁN
}

\author{
AREAS WITH POTENTIAL FOR COMMERCIAL TIMBER PLANTATIONS OF \\ Pinus pseudostrobus Lindl. AND Pinus greggii Engelm. IN MICHOACÁN
}

\author{
H. Jesús Muñoz Flores', J. Trinidad Sáenz Reyes', J. Jesús García Sánchez², \\ Edgar Hernández Máximo ${ }^{3}$ y José Anguiano Contreras'1,
}

\section{RESUMEN}

\begin{abstract}
El establecimiento de plantaciones forestales es una alternativa para recuperar terrenos degradados, disminuir las tasas de erosión y asegurar el abastecimiento a la industria. En Michoacán se han utilizado, con esa intención, varias especies de coníferas y hojosas, sin embargo, presentan una baja supervivencia y reducidos incrementos, en respuesta a factores como: el establecimiento sin un propósito específico, mala elección de especies, densidades inadecuadas para el buen desarrollo del arbolado y falta de manejo silvícola. El objetivo del presente estudio fue determinar áreas potenciales para plantaciones comerciales de Pinus pseudostrobus y P. greggii, en el estado de Michoacán. La delimitación de las áreas se realizó con los Sistemas de Información Geográfica (SIG) IDRISI 32, y ArcView. Para ambos taxa se consideraron las variables: uso y tipo de suelo, temperatura media anual, precipitación total anual, altitud y pendiente. Los resultados se verificaron en campo. Se generaron cuatro mapas con las áreas potenciales para las plantaciones, así como la superficie total para cada taxón. P. pseudostrobus se estimaron 234,766 ha, con pendiente 0-15\% y 99,760 ha (pendiente 15-30\%); para P. greggii 253,626 ha (pendiente 0-15\%) y 108,365 ha (pendiente 15-30\%). Se concluye que con el uso de los SIG para definir la ubicación de las plantaciones comerciales de las dos especies de Pinus se tienen mayores probabilidades de supervivencia, buenos incrementos, además de ser una herramienta confiable para determinar las áreas potenciales.
\end{abstract}

Palabras clave: Áreas potenciales, Michoacán, Pinus pseudostrobus Lindl., Pinus greggii Engelm. Plantaciones forestales comerciales, Sistema de Información Geográfica.

\begin{abstract}
The establishment of forest plantations is an alternative for recovering degraded land, reducing erosion rates and securing supplies for the forest industry. Various species of conifers and broadleaves have been used in plantations in Michoacán State, México. Experience shows low survival and poor growth due to various factors such as lack of purpose, unsuitable species, inappropriate stocking and insufficient of silvicultural treatments. The aim of this study was to determine the potential areas for commercial forest plantations of Pinus pseudostrobus and P. greggii in the State of Michoacán. Areas were identified using IDRISI 32, and ArcView software. Screening variables include: land use, soil type, mean annual temperature, annual precipitation, elevation, and slope. Products obtained were field verified. Potential areas for commercial forest plantation establishment are: for P. pseudostrobus 234.766 ha 10-15\% slope), and 99.760 ha ( $15-30 \%$ slope); for P. greggii 253.626 ha (0-15\% slope), and 108.365 ha ( 15 - $30 \%$ slope). Potential areas identified through GIS stand a better chance to reach survival and good growth goals.
\end{abstract}

Key words: Potential areas, Michoacán, Pinus psudostrobus Lindl., Pinus greggii Engelm. Commercial forest plantations, geographic information system.

Fecha de recepción: 9 de septiembre de 2007.

Fecha de aceptación: 11 de enero de 2011

\footnotetext{
' Campo Experimental Uruapan- Centro de Investigación Regional Pacífico Centro (CIR-PAC)-INIFAP. Correo-e: munoz.hipolitojesus@inifap.gob.mx

2 Facultad de Agrobiología. Universidad Michoacana de San Nicolás de Hidalgo.

${ }^{3}$ Campo Experimental "El Palmar", Centro de Investigación Regional Golfo Cento (CIR-GOC), INIFAP.
} 


\section{INTRODUCCION}

De acuerdo con la Organización de las Naciones Unidas para la Agricultura y la Alimentación (FAO) en el mundo existen aproximadamente 4,000 millones de hectáreas de bosque, el equivalente a $30 \%$ de la superficie terrestre. Sin embargo, cada año se reduce en 13 millones de hectáreas a causa de la deforestación o la tala selectiva, este ritmo de pérdida disminuye gracias a las plantaciones y la expansión natural de los bosques (FAO, 2005).

México, a nivel mundial, ocupa el $10^{\circ}$ lugar por la diversidad de sus bosques naturales, cuenta con una cobertura forestal que se calcula en alrededor de 141.7 millones de ha, de ellas 56.8 millones corresponden a zonas arboladas, de las cuales 30.4 millones pertenecen a bosques y 26.4 millones de hectáreas son de selvas (FAO, 2000).

A pesar de la vocación forestal, el país enfrenta serios y complejos problemas, como la deforestación y erosión de amplias extensiones de su territorio, como resultado de la tala clandestina, incendios forestales y el cambio de uso de suelo, lo que provocó la pérdida de 314,000 ha de bosques por año, para el periodo 2000-2005. La situación anterior se ha contrarrestado a través del establecimiento de plantaciones forestales con varias especies arbóreas (CONAFOR, 2005).

El estado de Michoacán tiene una extensión territorial de $59,864 \mathrm{Km}^{2}$, que representan 3.04\% del territorio nacional; ocupa el $5^{\circ}$ lugar por su biodiversidad y multiplicidad de recursos naturales. Su superficie arbolada es de aproximadamente 2'602,727 ha, de éstas, 1'544,353 ha corresponden a bosques templados, 1'058,374 ha a selvas y 247,846 ha se conforman de vegetación de zonas áridas, así como hidrófila y halófila. A pesar de ser una entidad eminentemente forestal, presenta un área con disturbio de 1' 355, 878 ha, que tiene entre sus principales causas el cambio de uso de suelo, el clandestinaje, la sobreexplotación, los incendios, plagas y enfermedades, que generan una tasa de deforestación estimada en 30 mil ha anuales (COFOM, 2003).

En las forestales se han utilizado una gran variedad de especies de coníferas y hojosas, las cuales presentan una baja supervivencia y reducidos incrementos, en respuesta a diversos factores como: el establecimiento sin un objetivo especifico, la mala selección de especies y densidades, así como a la falta de manejo silvícola (Sáenz et al., 2000).

Una herramienta que facilita la localización y delimitación de las zonas potenciales para la ubicación de plantaciones forestales comerciales son los Sistemas de Información Geográfica (SIG), (Sáenz et al., 2000). Carmona y Monsalve (1997) mencionan que un SIG es un sistema de hardware, software y procedimientos diseñados para la captura,

\section{INTRODUCTION}

According to United Nations Food and Agriculture Organization ( $F A O)$, there are around 4,000 million ha of forest land in the world. This figure represents nearly $30 \%$ of the global land area. However, this forest area declines at a rate of 13 million ha per year due to deforestation. Rate of loss has slowed down because of plantations and expansion of natural forests (FAO, 2005).

Mexico ranks $10^{\text {th }}$ place in the world because of the rich diversity in its natural forests. Mexican forests cover 141.7 million ha. Timber land in Mexico amounts to 56.7 million ha. Temperate forests occupy 30.4 million ha, and 26.4 million ha are covered by tropical forests (FAO, 2000).

Despite its considerable forestry potential, the country faces serious and complex problems such as land clearing and erosion of ample tracks of land. Deforestation has been the direct result of illegal logging, forest fires, and land use changes. In the 2000-2005 period deforestation averaged a net annual loss of 314,000 ha. This condition is being dimmed recently by forest plantations that use a number of forest tree species (CONAFOR, 2005).

Michoacán state is endowed with a $59,864 \mathrm{~km}^{2}$ territory, which amounts to a $3.04 \%$ of the national territory. Its natural wealth raises Michoacán to the $5^{\text {th }}$ place in national biodiversity. Timberlands represent nearly 2'602,727 ha. They contain 1'544,353 ha of temperate forests, 1'058,374 ha of tropical forests, and 247,846 ha of arid lands, wetlands and saline environments. Michoacán has 1'355,878 ha of degraded areas, even though it is a region with a tradition in forestry. Land clearings, illegal logging, overexploitation, forest fires, pests and diseases are the forces behind a deforestation rate of 30,000 ha per annum (COFOM, 2003).

Michoacán forest plantations have become testing grounds for a great variety of conifers and hardwoods. Usual outcomes are characterized by poor survival and reduced growth in response to diverse factors such as: absence of a specific reason for planting, wrong selection of species and stocking and limited silvicultural tending (Sáenz et al., 2000).

Geographic Information System (GIS) (Sáenz et al., 2000) is a convenient tool that facilitates geographic features location and delimitation. Carmona and Monsalve (1997) explain that it is a system composed of hardware, soffware and procedures designed to handle spatially explicit object and data processes such as input, administration, processing, analysis, modeling, and plotting. GIS help solve complex problems in planning and management. The United Nations Food and Agriculture Organization (FAO, 1999) defines as GIS those computer systems used in data storage, summarization and 
administración, manipulación, análisis, modelado y graficado de datos u objetos referenciados espacialmente, que ayudan a resolver problemas complejos de planeación y administración. La Organización de las Naciones Unidas para la Agricultura y la Alimentación (FAO) (1999) cita que el término SIG se aplica a los sistemas computarizados de almacenamiento, elaboración y recuperación de datos con equipo y programas específicamente diseñados para manejar información espacial de referencia geográfica y sus correspondientes atributos.

En México desde finales del siglo XX se han realizado diversos estudios sobre potencial productivo de especies vegetales que incluyen a coníferas de importancia económica como: P. michoacana Martínezy P. oocarpa Schiede (INIFAP, 1993); otros trabajos se refieren a la determinación de áreas para el aprovechamiento de Abies religiosa (HBK.) Schltdl. et Cham. (Ruiz y Rueda, 1994). También sobresalen estudios referentes a la distribución geográfica potencial de taxa con estatus de conservación, por ejemplo Picea chihuahuana Martínez (SAGAR e INIFAP, 1997).

Moreno y Moreno (1995) señalan que desde 1991 en el INIFAP se han llevado a cabo investigaciones a nivel nacional con la aplicación y uso de los SIG, principalmente para estudios de potencial productivo de especies vegetales, así como para el enriquecimiento y uso de la base de datos geográficos del propio instituto, cuyos resultados sirven de apoyo a la toma de decisiones en la planeación del uso de suelo.

Los SIG también constituyen una herramienta eficaz para los administradores de los programas de apoyo a las plantaciones, a futuro permitirá conocer la dinámica de su manejo y ofrecerá información tanto para el análisis económico de la actividad forestal, como para la generación de políticas de manejo (González, 2002).

León (2005) afirma que en el bosque de pino-encino de la Sierra de La Laguna, no se cuenta con una evaluación de la superficie que ocupa, ni del volumen leñosos que presentan sus principales especies. Con base en imágenes de satélite recientes se obtuvo una clasificación de unidades de vegetación, y se realizó un muestreo de campo para evaluar a las especies presentes, coniuntamente con datos dasonómicos. En fases subsiguientes se incorporaron los datos de campo dentro del SIG, con información ambiental basada en el Modelo Digital del Terreno de INEGl y la cartografía analógica 1:50,000, esta información se procesó en IDRISI-KLIMANJARO y en ArcView, georreferenciados en UTM ws.

Para obtener éxito en las plantaciones forestales comerciales debe asegurarse que las áreas seleccionadas cumplan con los requerimientos ecológicos propios de las especies que se utilizarán, con ello se logrará que los individuos tengan retrieval. GIS data management, according to $F A O$, is carried out with specially designed programs that handle geographic attributes of spatial information.

During the latter part of the $X X^{\text {th }}$ century several studies have been made in Mexico about the productive potential of plant species. These studies involve economically important species such as Pinus michoacana Martínez and P. oocarpa Schiede (INIFAP, 1993). Other research assessed Abies religiosa (HBK.) Schltdl. et Cham. harvest areas (Ruiz and Rueda, 1994). The study of the geographic range of potential presence of Picea chihuahuana Martínez and other legally protected taxa (SAGAR and INIFAP, 1997) is research worth mentioning too.

Moreno and Moreno (1995) point out that INIFAP has conducted research at the national level with GIS. The study of productive potential of crops frequently takes advantage of GIS. This research has enriched and promoted the use of INIFAP's geographic data bank. Results have provided support to decisions on land use planning.

GIS has become an effective tool for managers in charge of plantation support programs. In the future GIS applications will provide understanding about resource dynamics and its management, they will also offer information about forest economic analysis, and they will help to set forest management policies.

León (2005) expressed concern about area and timber stock of the pine-oak forest of Sierra de La Laguna have not been assessed. He produced vegetation cover estimates through satellite imagery classification. A field survey of species presence and dasometric data was carried out for validation. Field truth data was added to imagery data, and to ancillary environmental variables derived from INEGl's digital elevation model and analogic 1:50,000 charts. The final output product was created using IDRISI-KLIMANJARO and ARCVIEW software. Geographic references were coded as UTM.

Success in commercial forest plantations needs assurances that the selected sites meet species ecologic requirements. Trees planted this way will quickly adapt to the site (Rueda, 1998).

Literature reporting GIS applications in plantation site selection includes diagnostic studies in Jalisco (Rueda, 1998). Additionally, there are papers presenting maps of potential plantation sites in Michoacán for Eucalyptus (E. grandis W. Hill and E. urophylla S. T. Blake), (Reygadas et al., 2000) and conifers such as Abies religiosa (HBK.) Schltdl. et Cham., Pinus pseudostrobus Lindl., P. michoacana Martínez, P. montezumae Lamb., P. teocote Schied. ex Schltdl. et Cham., P. oocarpa Schiede, P. ayacahuite Ehrenb. ex Schltdl., P. lawsonii Roezl ex Gordon and P. herrerae Martínez. 
una adaptación rápida al área donde se establezcan (Rueda, 1998).

Respecto a la aplicación de los SIG en la definición de los sitios adecuados para el establecimiento de plantaciones, se pueden citar las investigaciones de tipo diagnóstico en Jalisco (Rueda, 1998); en el caso del estado de Michoacán los trabajos enfocados a la generación de mapas con las áreas potenciales para plantaciones del género Eucalyptus (E. grandis W. Hill y E. urophylla S. T. Blake) en el estado de Michoacán (Reygadas et al., 2000) y de coníferas que incluyen las siguientes especies: Abies religiosa (HBK.) Schltdl. et Cham., Pinus pseudostrobus Lindl., P. michoacana Martínez, P. montezumae Lamb., P. teocote Schied. ex Schltdl. et Cham., P. oocarpa Schiede, P. ayacahuite Ehrenb. ex Schltdl., P. lawsonii Roezl ex Gordon y P. herrerae Martínez.

\section{Requerimientos ambientales de Pinus pseudostrobus}

Especie originaria de México, Guatemala y Honduras (CATIE, 1997); ocurre en localidades cuya precipitación media anual varía de 1,000 a 1,500 mm, con un régimen de lluvia uniforme durante el verano, la estación seca puede ser de $\mathrm{O}$ a 3 meses; la temperatura máxima promedio del mes más cálido es de 20 a $26{ }^{\circ} \mathrm{C}$, la del mes más frío de $6-12{ }^{\circ} \mathrm{C}$ y la temperatura medio anual oscila de 12 a $19{ }^{\circ} \mathrm{C}$. En Michoacán se localiza en los macizos forestales con altitudes de 2,200 hasta $3,000 \mathrm{~m}$. Los suelos que prefiere son profundos, ácidos, pardos - cafés, de buen drenaje, con textura arena migajonosa a migajón arenoso, características que corresponden al tipo Andosol. Crece en sitios con suelos de buena calidad, aunque también se localiza en Regosoles, Cambisoles, Luvisoles, no de menor calidad y se desarrolla de manera aceptable en suelos con pH neutro a ligeramente ácidos, con textura media - pesada y que presenten buen drenaje, tal es el caso de la región suroccidental en "El Varaloso" y "Dos Aguas" donde se desarrolla bien en suelos de tipo Regosol y Luvisol (García, 1996).

P. pseudostrobus es buen productor de resina, por lo que se aprovecha en los estados del centro y sur de México. La madera es de buena calidad y sus largos y limpios fustes permiten su uso en aserrío, madera terciada, chapa, triplay, pulpa para papel, caballetes, molduras, jaulas y envases, como barrera de calor y sonido, postes, pilotes, madera para minas, durmientes para ferrocarril, tejamaniles y largueros, como combustible, palillos y fósforos. Es muy apreciada en artesanías, ebanistería y muebles finos o de producción seriada como: mesas, butacas, bancos, etc., en las zonas rurales tiene varios usos domésticos. Se propone emplearla en la fabricación de abatelenguas, palos para paleta, cucharas para nieve, pisos, canceles, tarimas y plataformas, entre otros (Eguiluz, 1978; Pérez y Olvera, 1981).

\section{Environmental requirements for Pinus pseudostrobus}

This species is a native of Mexico, Guatemala and Honduras (CATIE, 1997). Pinus pseudostrobus grows at sites with a mean annual precipitation between 1,000 and 1,500 mm, where rains fall evenly during summer; dry season may last from zero to three months. The hottest month may reach a mean temperature around 20 to $26{ }^{\circ} \mathrm{C}$, and the coldest month may cool down to 6 to $12^{\circ} \mathrm{C}$; mean annual temperature must stay within the 12 to $19^{\circ} \mathrm{C}$ range.

In Michoacán Pinus pseudostrobus starts at 2,000, and reaches up to $3,000 \mathrm{~m}$ in elevation. This species grows best in deep, acid, well drained soils. Brown is the usual soil color. Texture tends to be sandy loam to loamy sand, as it usually is the case of Andosols. P. pseudostrobus also grows on Regosols, Cambisols, Luvisols, as long as these sites are of similar productivity as Andosols. Soils can be lightly acid or have a neutral $\mathrm{pH}$, with medium to heavy texture, with good drainage, as is the case in El Varaloso and Dos Aguas, in Southwest Michoacán, where soils are Regosols and Luvisols (García, 1996).

Pinus pseudostrobus is a high yield resin producer, a feature that is appreciated in the Center and South of Mexico. Its wood is high quality and its long clear stems favor lumber production, as well as plywood, pulpwood, firewood, veneer, roofing shingles, poles, mining posts, railroad ties, trimmings, cages, boxes, sound and heat insulation, sticks, and matches. This wood is excellent for handicrafts, fine furniture, and manufactured products such as tables, chairs, lounges, stools, etc. It is widely used in domestic rural applications. Utilization as flooring material, cabinets, pallets, platforms, walls, lollipop sticks, disposable spoons, and other uses has been suggested (Eguiluz, 1978; Pérez and Olvera, 1981).

\section{Environmental requirements for Pinus greggii Engelm.}

This pine is a native of Mexico (Martínez, 1948), and it is similar to Pinus patula Schlecht. et Cham., except for having short, straight, thick needles.

Pinus greggii has a wide though spotted distribution throughout Sierra Madre Oriental. Diverse environmental conditions occur in this distribution range. Eguiluz (1978) indicates that Pinus greggii grows frequently in a subtropical climate with variable annual precipitation of at least $500 \mathrm{~mm}$, but best if between 700 and 1,500 mm. Rain tends to fall mostly in May to October, with heavy precipitation during July and August. March should be the driest month. Mean temperature must be close to $16.8{ }^{\circ} \mathrm{C}$, with extreme values of 45 and $-9{ }^{\circ} \mathrm{C}$. March and August tend to be the hottest months; the coldest are the winter months. Up to 74 frost events can occur throughout the year in the northern part of the distribution range, but only 24 in the Southern portion. 
Requerimientos ambientales de Pinus greggii Engelm.

Especie forestal nativa de México (Martínez, 1948), parecida a P. patula Schlecht. et Cham., pero se diferencia por sus hojas cortas, derechas y gruesas.

Dada su distribución amplia pero muy discontinua por la Sierra Madre Oriental se presenta en diferentes condiciones ambientales. Eguiluz (1978) menciona que se desarrolla en un clima subtropical, con precipitación variable de $500 \mathrm{~mm}$, es más frecuente en lugares con registros de 700 a 1,500 mm anuales, repartidos de mayo a octubre, julio y agosto son los meses más lluviosos y marzo el más seco. Temperatura media de $16.8^{\circ} \mathrm{C}$, con extremas máximas de $45^{\circ} \mathrm{C}$ y mínimas de $-9{ }^{\circ} \mathrm{C}$. Los meses más cálidos son de marzo a junio y los más fríos en invierno, cuando pueden presentarse hasta 74 heladas anuales hacia el norte de su área de distribución y máximo 20 en el sur.

Dvorak y Donahue (1993) consignan que los sitios de P. greggii en el norte de México son secos con una precipitación anual de 400 a 600 mm. Las heladas son frecuentes de diciembre a febrero. Las localidades del centro de México tienen una precipitación anual de 700 a 1,600 mm.

En forma natural crece, principalmente, en las montañas de la Sierra Madre Oriental en altitudes de 1,300 hasta $3,000 \mathrm{~m}$ y de 2,000 a 3,100 m. Sin embargo, el intervalo de distribución altitudinal varía de acuerdo a los autores, que lo ubican de 1,200 a 2,700 m (Din, 1958; Eguiluz, 1978; Dvorak, y Donahue, 1993). Habita en suelos delgados, de textura migajón areno-arcilloso, pedregosos, café rojizos y calizos, normalmente pobres en materia orgánica; con pH casi neutro (Equiluz, 1978). Mientras que Dvorak y Donahue (1993) citan para las procedencias del norte de México suelos ligeramente alcalinos con pH de 7-8; en tanto que las del centro con mayor frecuencia son ácidos de $\mathrm{pH} 4.0$ a 5.0 .

La madera de $P$. greggii, en su mayor parte, se destina al aserrío, también se usa para durmientes, pilotes para minas, vigas y postes para cercas, muebles y leña (Eguiluz, 1978; Pérez y Olvera, 1981). La recomiendan para la construcción (estructuras secundarias), ebanistería, decoración de interiores, lambrín y duelas para cielos rasos (Pérez y Olvera 1981).

El objetivo del presente estudio fue localizar y delimitar áreas potenciales para el establecimiento de plantaciones forestales comerciales de Pinus pseudostrobus y $P$. greggii en Michoacán, mediante el uso de Sistemas de Información Geográfica (SIG).

\section{MATERIALES Y MÉTODOS}

El área de estudio fue el estado de Michoacán, localizado en la porción occidente del país, entre las coordenadas
Dvorak and Donahue (1993) describe Pinus greggii sites in Northern Mexico as dry, with an annual precipitation from 400 to $600 \mathrm{~mm}$. Frost is common from December to February. Localities in central Mexico tend to receive 700 to $1,600 \mathrm{~mm}$ of annual rain.

Pinus greggii's natural habitat occurs in the mountains of Sierra Madre Oriental, at elevations ranging from 1,300 up to $3,000 \mathrm{~m}$.

Soils for this tree can be shallow, sandy-clay in texture, brown reddish color, rocky, and with calcareous physical structure. These soils are normally poor in organic matter and $\mathrm{pH}$ tends to be neutral (Eguiluz, 1978). Dvorak and Donahue (1993) reported lightly alkaline sites in Northern Mexico, with a $\mathrm{pH}$ of 7 to 8 , but central localities are frequently acid, meaning a $\mathrm{pH}$ of 4 to 5 .

Utilization of Pinus greggii's wood is recommended for lumber, railroad ties, mining poles, beams, posts, fences, furniture and firewood (Eguiluz, 1978; Pérez and Olvera, 19816). This wood performs well in applications such as construction (temporary support structures), fine woodworking, interior trimmings, floors, roofs and ceilings (Pérez and Olvera, 1981).

This paper's objective was to locate and define potential areas for commercial forest plantations of Pinus pseudostrobus and P. greggii in Michoacán, through the use of geographic information systems (GIS).

\section{MATERIALS AND METHODS}

The state of Michoacán in Western Mexico was the study area. Coordinates for Michoacán are 100 $04^{\prime} 45^{\prime \prime}$ W to 103 44'49" W, and $20^{\circ} 23^{\prime} 43^{\prime \prime} \mathrm{N}$ to $18^{\circ} 09^{\prime} 47^{\prime \prime} \mathrm{N}$. Michoacán territory expands $59,864 \mathrm{~km}^{2}$ (INEGI, 1985), and it is Northwest of Guerrero, North of the Pacific Ocean, South from Guanajuato and Querétaro, and East of Colima and Jalisco. Michoacán is administratively divided into 113 municipalities (Figure 1).

Climate in Michoacán is explained by one geographic factor: changes in elevation caused by a broken topography. Michoacán is characterized by a series of mountain ranges parallel to the coastline. Climate patterns tend to be predominantly sub-humid with summer rains and a sharply defined winter dry season (INEGI, 1985). Topography separates two climate regions: a) Sierra Madre del Sur and Southern slope of Eje Neovolcánico. This region displays climates from hot to temperate, depending on elevation, and there is also a North to South moisture gradient. b) Eje Neovolcánico (except the Southern slopes). This region displays East to West bands of temperate climates that cover the Northern and central part of the State. Northern bands change southward from hot to cold and again to hot (Ortíz, 1987). 
$100^{\circ} 04^{\prime} 45^{\prime \prime} 103^{\circ} 44^{\prime} 49^{\prime \prime}$ de longitud W y $20^{\circ} 23^{\prime} 43^{\prime \prime} 18^{\circ} 09^{\prime} 47^{\prime \prime}$ de latitud N; posee un territorio de $59,864 \mathrm{~km}^{2}$ (INEGI, 1985), colinda al N con los estados de Guanajuato y Jalisco, al NW con el estado de Querétaro, al E con el Estado de México, al SE con Guerrero, al S con el Océano Pacífico, al W con Colima y la parte sur de Jalisco. Está conformado por 113 municipios (Figura 1).
Predominant soils in the state derive from volcanic ash (Andosols). These soils occur at Eje Neovolcánico and Sierra Madre del Sur. In this edaphic province, Vertisols also appear at ranges and valleys. On hills and mountains Leptosols, Luvisols, and Feozems they might be present. Andosols dominate Meseta Tarasca. Soils from Sierra Mil Cumbres at high elevation sites are also Andosols. Acrisols and Luvisols are found at piedmonts,

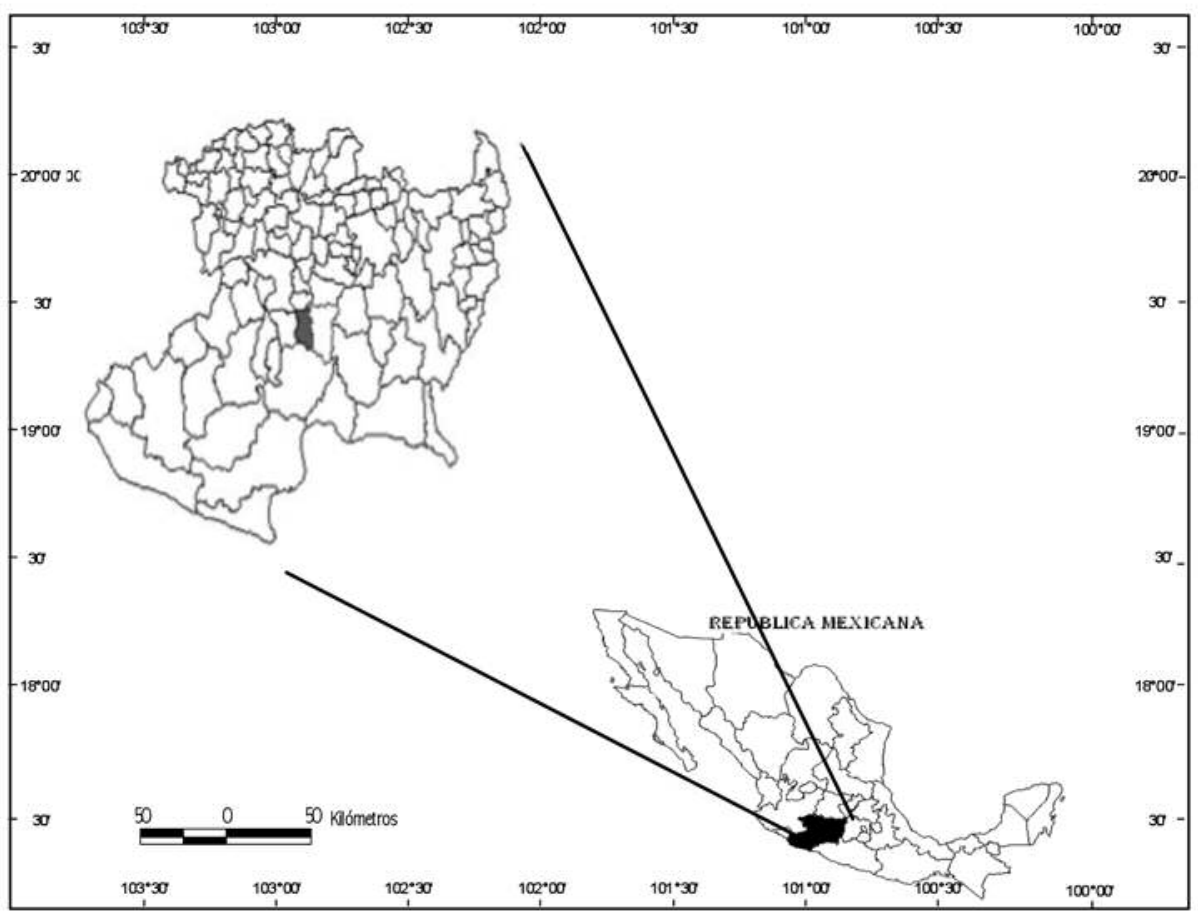

Figura 1. Ubicación geográfica del área de estudio en el estado de Michoacán.

Figure 1. Geographic location of Michoacán, the study area.

La distribución climática en la entidad está relacionada a tres factores geográficos: los contrastes altimétricos del relieve; que se caracteriza por la presencia de una serie de cadenas montañosas que se alinean paralelamente a la costa y el régimen de humedad predominante es el subhúmedo con lluvias en verano y una estación invernal seca bien definida (INEGI, 1985).

Por sus características climáticas se distinguen en el estado dos grandes áreas: a) Climas de la Sierra Madre del Sur y de la Escarpa Limírrofe del Sur (Eje Neovolcánico). En esta región varían de cálidos a templados en función de la altitud y de la menor a mayor humedad que se manifiesta de norte a sur. b) Climas del Eje Neovolcánico lexcepción de la Escarpa Limítrofe del Sur). Comprenden la porción septentrional y central de la entidad; se distribuyen en una serie de franias ubicadas de oriente a poniente y se clasifican dentro del grupo de los templados. De norte a sur cambian de manera gradual de cálidos a fríos y nuevamente a cálidos (Ortiz, 1987). creeks and valleys. Feozems normally can be seen at the edge of crop lands. Low lands and flat ground places with non-irrigated and irrigated agriculture, or natural vegetation of subtropical woodlands and grasslands tend to have Vertisols. Leptosols are distributed in random patterns associated to steep terrain and rocky outcrops (FAO-UNESCO, 1975).

Temperate, cold, and tropical low and medium forests, arid vegetation cover types are represented among Michoacán ecosystems. They add up to $67.7 \%$ of the land cover. Temperate and cold forests grow in the mountains of Eje Neovolcánico and Sierra Madre del Sur. Composition of these forests includes pine, fir, oak and mixed forests (COFOM, 2003).

Medium tropical forest can be seen at the Cordillera and coastal region. These forests are characterized by trees 15 to $25 \mathrm{~m}$ in height. Low tropical forest appears at the coast, on the lower ranges of Cordillera Sur Occidental, Tepalcatepec basin, and Balsas basin. This cover type commonly forms transitional gradients changing into pine-oak forest. Low tropical forests are 
En el estado predominan los suelos derivados de cenizas volcánicas (andosoles), los cuales se localizan en el Sistema Volcánico Transversal y la Sierra Madre del Sur. En la provincia del Eje Neovolcánico y Sierra Madre del Sur se presentan vertisoles en llanuras y valles íntermontanos; se asocian con Leptosoles, Luvisoles y Feozem en cerros y lomeríos. Al centro, en la zona de la Meseta Tarasca, dominan los Andosoles. En la Sierra de Mil Cumbres, los Andosoles ocurren en las partes más elevadas. Los Acrisoles y Luvisoles, se sitúan en laderas de cerro, en barrancas y valles. Los Feozem se encuentran, normalmente, en la frontera agrícola. En las partes más bajas y en terrenos planos con vegetación natural de matorral subtropical, pastizal y agricultura de temporal y de riego se ubican los Vertisoles. Los Leptosoles se distribuyen irregularmente en terrenos de pendiente fuerte en el malpaís (FAO-UNESCO, 1975).

Los bosques de clima templado frío y las selvas medianas y bajas, así como las zonas áridas, representan los tipos de ecosistemas más importantes en Michoacán, con $67.7 \%$ de la superficie forestal total. Los primeros se desarrollan en los macizos montañosos del Eje Neovolcánico y la Sierra Madre del Sur. Este tipo de vegetación lo componen bosques de pino, de oyamel, bosques mezclados y bosques de encino (COFOM, 2003).

En la Cordillera y Región Costera del estado, en climas cálidos y húmedos se distribuyen las selvas medianas, constituidas por arbolado de 15 a $25 \mathrm{~m}$ de altura. Las selvas bajas existen, en la Región Costera, en las estribaciones de la Cordillera Sur Occidental, en la Depresión del Tepalcatepec y en la Depresión del Balsas; además es común en zonas de transición con bosques de pino-encino. Sus componentes arbóreos presentan alturas entre 4 y $15 \mathrm{~m}$, casi todos pierden las hoias por largos periodos durante el año (COFOM, 2003).

La vegetación de zonas áridas está compuesta por comunidades de mezquite y huizache que se caracterizan por ser árboles bajos, espinosos de 4 a $15 \mathrm{~m}$ de altura (COFOM, 2003).

Michoacán se ubica en la porción oeste de la provincia del Eje Neovolcánico y en la provincia de la Sierra Madre del Sur. En el Eje Neovolcánico se localiza casi la totalidad de la cuenca del Río Lerma, pues sólo quedan fuera de ella los afluentes que proceden de la mesa del centro y la conforman parte de ocho subprovincias: Neovolcánica Tarasca, las Sierras y Bailos Michoacanos, Mil Cumbres de la Escarpa Limítrofe del Sur, Chapala, Del Baiío Guanajuatense, las Ilanuras y Sierras de Qverétaro e Hidalgo, los Lagos y Volcanes de Anáhuac (COFOM, 2003).

La provincia de la Sierra Madre del Sur comprende porciones de cuatro subprovincias y la totalidad de una discontinuidad: la Cordillera Costera del Sur, la Depresión made up of trees 4 to $15 \mathrm{~m}$ in height, and these trees appear without leaves most of the year (COFOM, 2003).

Arid vegetation cover includes mesquite and huizache communities with thorny trees 4 to $15 \mathrm{~m}$ in height (COFOM, 2003).

Watersheds in Michoacán belong to the Eje Neovolcánico and Sierra Madre del Sur hydrologic provinces. Most of the Eje Neovolcánico province belongs to Río Lerma watershed, except streams descending from the central plateau. This province can be broken down into subprovinces: Neovolcánica Tarasca, Sierras and Bajíos Michoacanos, Mil Cumbres de la Escarpa Limítrofe Sur, Chapala, Del Baijo Guanajuatense, Llanuras and Sierras of Querétaro e Hidalgo, Los Lagos and Volcanes de Anáhuac (COFOM, 2003).

Sierra Madre del Sur encompasses four subprovinces, and an entire discontinuity: Cordillera Costera del Sur, Depresión del Balsas, Costas del Sur, Discontinuidad Fisiográfica de la Depresión de Tepalcatepec, Sierras de la Costa de Jalisco y Colima (INEGI, 1984).

The broken terrain has formed three runoff patterns: Northern, where Cuitzeo, Pátzcuaro, Chapala and Zirahuén lakes are fed by Río Lerma. Center, where Río Tepalcatepec and Balsas rivers run. And South or Pacific, where streams descending from Sierra de Coalcomán reach the Pacific Ocean.

In this paper forest plantation potential areas in Michoacán were defined considering the regionalization of the Comisión Forestal del Estado de Michoacán (COFOM). This scheme classifies municipalities into ten forest regions (Table 1).

Regionalization criteria follows mainly forest cover, watersheds and timber stocking (Figure 2).

The search scheme for potential areas chose sites meeting the following environmental features for each species studied: elevation, total annual precipitation, mean annual temperature, slope, land use, and soil type (Table 2).

IDRISI 32 (4.0) software was used to produce maps and estimates of area with potential for commercial forest plantations of Pinus pseudostrobus and P. greggii. IDRISI is one of many commercial software products that handle GIS data bases. Charts, imagery and climate digital information from Instituto Nacional de Investigaciones Forestales, Agrícolas y Pecuarias (INIFAP, 2003) were used. The Digital Elevation Model (DEM) employed had a $360 \mathrm{~m} \times 360 \mathrm{~m}$ resolution, equivalent to $12.96 \mathrm{ha}$, that is, each pixel (cell) covers this area; all variables were measured within this spatial frame.

Screening sorted sites using RECLASS command. This routine excludes pixels that do not meet stated species habitat criteria. A 
del Balsas, las Costas del Sur, discontinuidad fisiográfica de la Depresión de Tepalcatepec, las Sierras de la Costa de Jalisco y Colima (INEGI, 1984).

Dado lo accidentado del relieve se han formado tres vertientes: la del norte donde se ubican los lagos de Cuitzeo, Pátzcuaro, Chapala y Zirahuén en la que escurre el Río Lerma; la del centro con los Ríos Tepalcatepec y Balsas y la del sur o del Pacífico, en la que los escurrimientos de la Sierra de Coalcomán desembocan directamente al Océano Pacífico (INEGI, 1985).

La determinación de las áreas potenciales para plantaciones forestales comerciales en Michoacán, se hizo con base en la regionalización de la Comisión Forestal del Estado de Michoacán (COFOM), que divide la entidad en 10 regiones forestales delimitadas por municipios (Cuadro 1). hierarchical screening sequence was designed for this purpose, according to the following categories or fitness classes:

Unsuitable $=0 \quad$ Sites lacking required ecological features for growth and development of the studied taxon.

Suitable $=1 \quad$ Sites that offer the required ecological features for a certain species

GIS thematic layers displayed each variable and its range of values spread throughout the geographic distribution range of Pinus pseudostrobus and $P$. greggii.

These layers were then joined through OVERLAY command. The resulting product represents the potential areas in RASTER

Cuadro 1. Municipios que integran las regiones forestales de Michoacán, de acuerdo a la Comisión Forestal del estado de Michoacán (COFOM), 2005

Table 1. Municipalities and Michoacán forest regions, according to the Comisión Forestal del Estado de Michoacán (COFOM, 2005).

\begin{tabular}{|c|c|}
\hline Región & Municipios \\
\hline I. Lerma-Chapala & $\begin{array}{l}\text { Briseñas, Chavinda, Cojumatlán, Ixtlán, Jacona, Jiquilpan, Marcos Castellanos, Pajacuarán, Purépero, } \\
\text { Sahuayo, Tangamandapio, Tangancícuaro, Tlazazalca, Venustiano Carranza, Villamar, Vista } \\
\text { Hermosa, Zamora. }\end{array}$ \\
\hline ॥. Baiío & $\begin{array}{l}\text { Angamacutiro, Coeneo, Churintzio, Ecuandureo, Huaniqueo, Jiménez, José Sixto Verduzco, Morelos, } \\
\text { Numarán, Penjamillo, La Piedad, Paníndicuaro, Puruándiro, Tanhuato, Yurécuaro, Zináparo, Zacapu. }\end{array}$ \\
\hline III. Cuitzeo & $\begin{array}{l}\text { Acuitzio, Álvaro Obregón, Copándaro, Cuitzeo, Charo, Chucándiro, Huandacareo, Indaparapeo, } \\
\text { Morelia, Queréndaro, Santa Ana Maya, Tarímbaro, Zinapécuaro. }\end{array}$ \\
\hline IV. Oriente & $\begin{array}{l}\text { Angangeo, Aporo, Contepec, Epitacio Huerta, Hidalgo, Irimbo, Juárez, Jungapeo, Maravatío, } \\
\text { Ocampo, Senguio, Susupuato, Tlalpujahua, Tuxpan, Tuzantla, Tiquicheo, Tzitzio, Zitácuaro. }\end{array}$ \\
\hline V. Tepalcatepec & $\begin{array}{l}\text { Aguililla, Apatzingán, Buenavista, Cotija, Tepalcatepec, Tingüindín, Tocumbo, Parácuaro, Peribán, Los } \\
\text { Reyes. }\end{array}$ \\
\hline VI. Meseta Tarasca & $\begin{array}{l}\text { Charapan, Cherán, Chilchota, Nahuatzen, Nuevo Parangaricutiro, Paracho, Tancítaro, Taretan, } \\
\text { Tingambato, Uruapan, Ziracuaretiro. }\end{array}$ \\
\hline VII. Pátzcuaro-Zirahuén & Erongarícuaro, Huiramba, Lagunillas, Pátzcuaro, Quiroga, Salvador Escalante, Tzintzuntzan. \\
\hline VIII. Tierra caliente & Carácuaro, Huetamo, Madero, Nocupétaro, San Lucas, Tacámbaro, Turicato. \\
\hline IX. Costa & Aquila, Arteaga, Coahuayana, Coalcomán, Chinicuila, Lázaro Cárdenas, Tumbiscatío. \\
\hline X. Infiernillo & Ario de Rosales, Churumuco, La Huacana, Gabriel Zamora, Múgica, Nuevo Urecho. \\
\hline
\end{tabular}

La regionalización se fundamenta, principalmente, en los siguientes conceptos: la vegetación forestal (base inicial), las cuencas hidrológicas y el volumen maderable de las existencias reales totales (Figura 2). format. Command AREA produced a quantitative estimate of potential area. IDRISI command REFORMAT was used to convert to vectorial format, and then exporting it to SHAPEFLLE for further work on ARCVIEW 3.2. GIS software for rendering $1: 100,000$ and $1: 250,000$ scale outputs. 


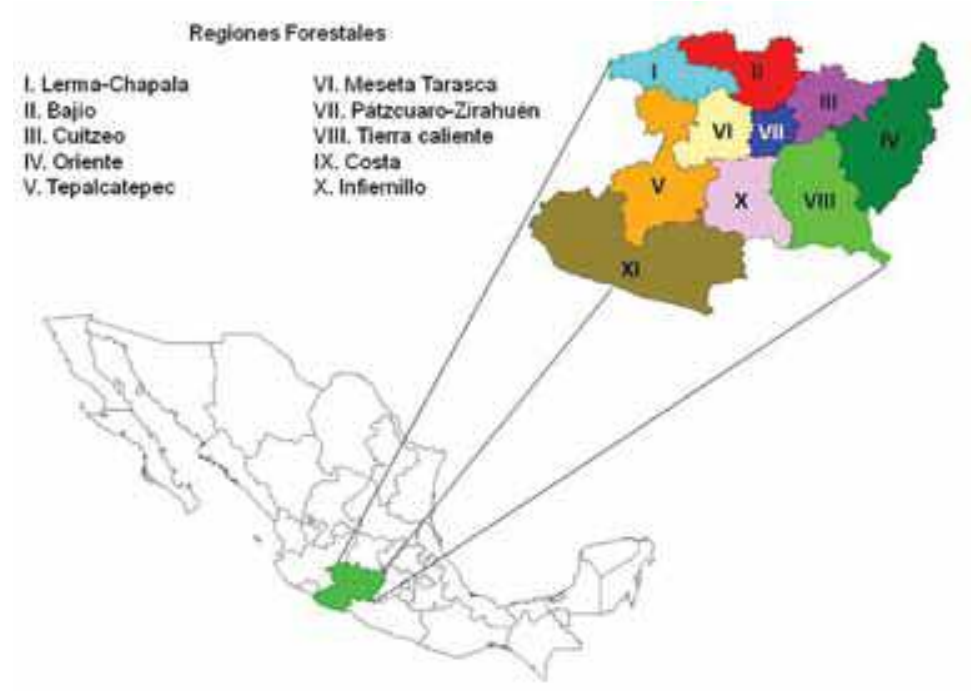

Figura 2. Regionalización del Estado de Michoacán (COFOM, 2005). Figure 2. Regions of Michoacán (COFOM, 2005).

La estimación de las áreas potenciales para cada una de las especies en estudio se realizó a partir de los siguientes requerimientos ambientales: altitud, precipitación total anual, temperatura media anual, pendiente, uso de suelo y tipo de suelo del estado (Cuadro 2).
Selected sites within the potential zones for each of the studied species were visited in the field to assess the existence of suitable ecologic conditions known to favor development of the pine species of interest, and therefore considered suitable for commercial forest plantations.

Cuadro 2. Requerimientos ambientales considerados para determinar las áreas potenciales para plantaciones forestales comerciales de Pinus pseudostrobus Lindl. y P. greggii Engelm., en Michoacán.

Table 2. Environmental requirements considered to assess sites potentially suitable for commercial forest plantations of Pinus pseudostrobus Lindl. and P. greggii Engelm. in Michoacán.

\begin{tabular}{|c|c|c|}
\hline Requerimientos & Pinus pseudostrobus & Pinus greggii \\
\hline Tipo de suelo & $\begin{array}{r}\text { Andosol (Regiones II, II, III, IV, V, VI, VII, VIII y X), para la región } \\
\text { IX fueron: Feozem, Luvisol, Cambisol, Andosol, }\end{array}$ & Andosol \\
\hline Temperatura media anual & $\begin{array}{l}\text { Regosol y Acrisol. } \\
12-19^{\circ} \mathrm{C}\end{array}$ & $10-15^{\circ} \mathrm{C}$ \\
\hline Precipitación total anual & $900-1,500 \mathrm{~mm}$ & $800-1,500 \mathrm{~mm}$ \\
\hline Altitud & $2,200-2,800 \mathrm{~mm}$ & $1,500-1,800 \mathrm{~mm}$ \\
\hline Pendiente & $0-15 \%$ y de $15-30 \%$ & $0-15 \%$ y de $15-30 \%$ \\
\hline Uso de suelo & \multicolumn{2}{|c|}{$\begin{array}{c}\text { Agricultura de riego y temporal, plantación forestal, bosque de pino, de pino-encino, de encino y } \\
\text { mesófilo de montaña, selva baja mediana y matorral subtropical. }\end{array}$} \\
\hline
\end{tabular}

La elaboración de los mapas y estimación de las áreas potenciales para el establecimiento de plantaciones forestales comerciales con Pinus pseudostrobus, y P. greggii, se realizó con el programa IDRISI 32 versión 4.0, uno de los software que trabaja con Sistemas de Información Geográfica (SIG). Se utilizó la información cartográfica y climática digital del Instituto Nacional de Investigaciones Forestales, Agrícolas y Pecuarias (INFAP, 2003). La resolución del modelo de elevación digital (DEM) fue de $360 \mathrm{~m} \times 360 \mathrm{~m}$, que equivale a 12.96 ha, es decir, a cada pixel (celda) le correspondió esta superficie y esa misma se usó para todas las variables.

\section{RESULTS AND DISCUSSION}

Four maps were produced showing sites with potential for developing plantations with Pinus pseudostrobus and $P$. greggii. For each species two site slope classes were selected, one with a slope between $0 \%$ to $15 \%$ for mechanized plantations. This case refers to spaces were irrigated and dryland agriculture is possible, and therefore forest plantation site preparation and timber harvest maneuvers can be mechanized. The other site class was selected in the $15 \%$ to $30 \%$ slope range, assuming manual planting for these conditions. 
Los mapas se generaron con el comando RECLASS, por medio del cual se descartaron las áreas del estado que no reunieron las características específicas para cada especie. Para ello se diseñó un sistema de estratificación de las zonas potenciales, el cual se basó en las siguientes categorías o niveles de aptitud:

No apto = 0 Comprende áreas que no presentan condiciones ecológicas propicias para el desarrollo y crecimiento de los taxa en estudio.

Áreas aptas $=1$ Incluye las áreas o regiones que garantizan la adaptación de las especies, al presentar las condiciones ecológicas propicias para su desarrollo.

Las cubiertas contienen, en forma individual, el intervalo de cada variable asociada a la distribución de P. pseudostrobus., y P. greggii.

Las imágenes obtenidas se sobrepusieron mediante el comando OVERLAY para obtener las áreas potenciales por especie en formato RASTER. A través del comando AREA se calculó la superficie. A continuación con el SIG IDRISI 32, y su comando REFORMAT se convirtieron a vector, posteriormente, se exportó cada uno de ellos a formato "shapefile" para trabajar en el SIG Arcliew versión 3.2, con el cual se generaron imágenes escala 1:100,000 y 1:250,000.

Se realizaron visitas de campo a puntos específicos de las zonas potenciales para cada una de las especies estudiadas, esto se hizo con el propósito de comprobar la existencia de las condiciones ecológicas adecuadas para el desarrollo de los pinos de interés y por lo tanto, para el establecimiento de plantaciones forestales comerciales (PFC).

\section{RESULTADOS Y DISCUSIÓN}

Se generaron cuatro mapas que muestran las áreas potenciales para la ubicación de plantaciones con P. pseudostrobus y P. greggii. En ambos casos se consideraron dos pendientes, una de 0-15\% para plantaciones mecanizadas, éstas corresponden a zonas agrícolas de riego y temporal, donde es factible realizar la preparación del terreno o las actividades de mantenimiento y extracción de productos con el uso de maquinaria. La otra pendiente fue de $15-30 \%$ para las no mecanizadas o manuales.

\section{Áreas potenciales para Pinus pseudostrobus}

Las áreas potenciales para el establecimiento de mecanizadas se localizaron en las 10 regiones forestales del estado, con un total de 234,766 ha (Figura 3 y Cuadro 3).
Potential areas for Pinus pseudostrobus

Areas suitable for this species were found in all ten forest regions in the State, they add up to 234,766 ha (Figure 3, Table 3). A total of 99,760 ha with slopes $15 \%$ to $30 \%$ were also found feasible for commercial forest plantations.

These steeper sites occur in all ten forest regions, including all municipalities previously listed as having suitable sites with near level slopes (Figure 4, Table 3).

Eguiluz (1978) considers that Pinus pseudostrobus distribution in Mexico spans from $17^{\circ} 15^{\prime} \mathrm{N}$ up to $29^{\circ} 15^{\prime} \mathrm{N}$, and $92^{\circ} \mathrm{O} 5^{\prime} \mathrm{W}$ to $108^{\circ} 35^{\prime}$ W, over Sierra Madre Oriental, Eje Neovolcánico, Sierra Madre del Sur, Sierra Madre de Chiapas and part of Sierra Madre Occidental. Martínez (1948), and Perry (1991) found this species in Jalisco, Colima, Michoacán, Estado de México, Hidalgo, Distrito Federal, Guerrero, Morelos, Oaxaca, Coahuila, Chihuahua, Guanajuato, Chiapas, Puebla, Querétaro, Nuevo León, San Luís Potosí, Tamaulipas, Veracruz, and Tlaxcala. Elevation varies from 1,600 to $2,400 \mathrm{~m}$, soils are yellowish brown, pH 4.5 to 7 , humus 10 to $30 \mathrm{~cm}$, soil depth 1 to $3 \mathrm{~m}$, and high nitrogen content, as it is characteristic of Andosols.

Madrigal (1982) found Pinus pseudostrobus present in several Michoacán regions: East, Southwest, and central (Sierra Purhépecha). Elevations registered start at 2,200 m and they go up to $3,000 \mathrm{~m}$ in Angangueo, Ciudad Hidalgo, Coalcomán, Los Reyes, Paracho, Uruapan, Nuevo San Juan Parangaricutiro, Tacámbaro, Tancítaro, and Villa Madero. Results in this study follow closely Madrigal, except Angangueo.

García ( 1996) reported a mean annual precipitation greater than 1,500 mm at Sierra Purhépecha, as well as a mean annual temperature of $16.9^{\circ} \mathrm{C}$. These parameters are close to environmental criteria used in the screening in this study.

\section{Areas with potential for Pinus greggii}

Some 253,623 ha were found suitable for mechanized establishment of Pinus greggii commercial forest plantations. These sites are distributed throughout all regions except IX (Figure 5, Table 4).

In a pattern similar to the one observed in Pinus pseudostrobus, P. greggii Meseta Tarasca concentrated in a larger area, slightly smaller than that for $P$. pseudostrobus. This region is closely followed by the Pátzcuaro-Zirahuén region, where potential areas for $P$. greggii were larger than for $P$. pseudostrobus at the same slope class $(0 \%$ to $15 \%$.

Pinus greggii sites with slope between $15 \%$ and $30 \%$ represent a total of 108,365 ha. These sites belong to the same 


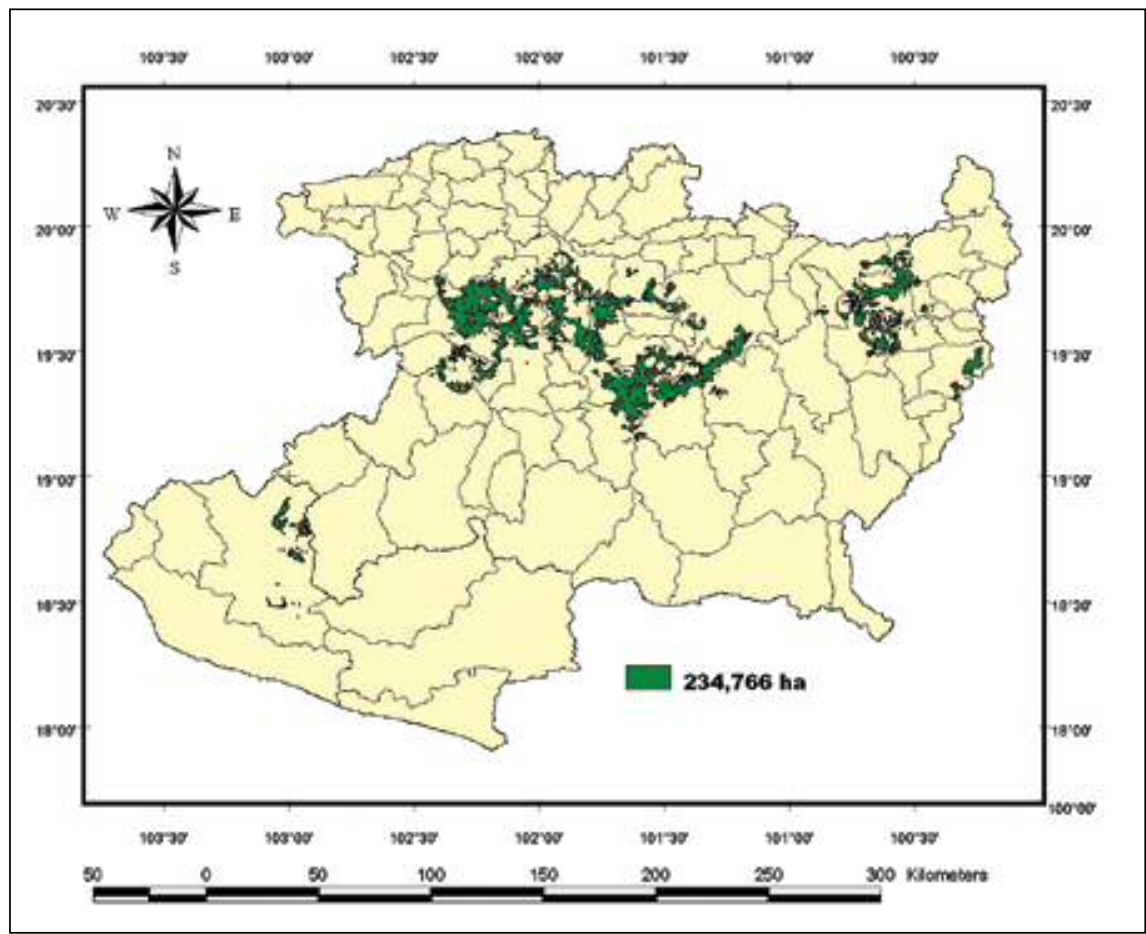

ESTADO DE MICHOACÁN

ÁREAS POTENCIALES

Pinus pseudostrobus

SIMBOLOGÍA

Áreas potenciales

234,766 ha

Cuerpos de agua

$\simeq$ Límite municipal

$\triangle \quad$ Cabecera municipal

Figura 3. Áreas potenciales para el establecimiento de plantaciones forestales comerciales mecanizadas de P. pseudostrobus Lindl., en Michoacán (pendiente 0-15\%).

Figure 3. Areas with potential for mechanized establishment of commercial plantations of Pinus pseudostrobus Lindl. in Michoacán (slope $0 \%$ - $15 \%$ ).

En el caso de las PFC con pendiente de $15-30 \%$ se estimaron 99,760 ha, distribuidas en las diez regiones forestales y en los mismos municipios que se indicaron para el otro intervalo de pendiente (Cuadro 3 y Figura 4). municipalities as $0 \%$ to $15 \%$ slope sites in Lerma-Chapala Baío, Cuitzeo, Oriente, Tepalcatepec, Meseta Tarasca, Pátzcuaro-Zirahuén, Tierra Caliente and Infiernillo. The coastal region turned out unfeasible for manual plantations (Table 4, Figure 6).

Cuadro 3. Superficie potencial estimada (ha) para el establecimiento de plantaciones forestales comerciales de Pinus pseudostrobus Lindl., en Michoacán.

Table 3. Area of potential sites (ha) suitable for commercial forest plantations of Pinus pseudostrobus Lindl., in Michoacán.

\begin{tabular}{|c|c|c|}
\hline \multirow[b]{2}{*}{ Región } & \multicolumn{2}{|c|}{ Pendiente } \\
\hline & $\begin{array}{c}0-15 \% \\
\text { (ha) }\end{array}$ & $\begin{array}{c}15-30 \% \\
\text { (ha) }\end{array}$ \\
\hline I. Lerma-Chapala & 955 & 1,703 \\
\hline ॥l. Baiío & 12,705 & 7,358 \\
\hline III. Cuitzeo & 17,852 & 6,784 \\
\hline IV. Oriente & 36,979 & 19,188 \\
\hline V. Tepalcatepec & 17,351 & 3,748 \\
\hline VI. Meseta Tarasca & 74,809 & 37,056 \\
\hline VII. Pátzcuaro-Zirahuén & 44,959 & 11,301 \\
\hline VIII. Tierra caliente & 14,551 & 4,168 \\
\hline IX. Costa & 7,702 & 6,861 \\
\hline X. Infiernillo & 6,903 & 1,593 \\
\hline Total & 234,766 & 99,760 \\
\hline
\end{tabular}




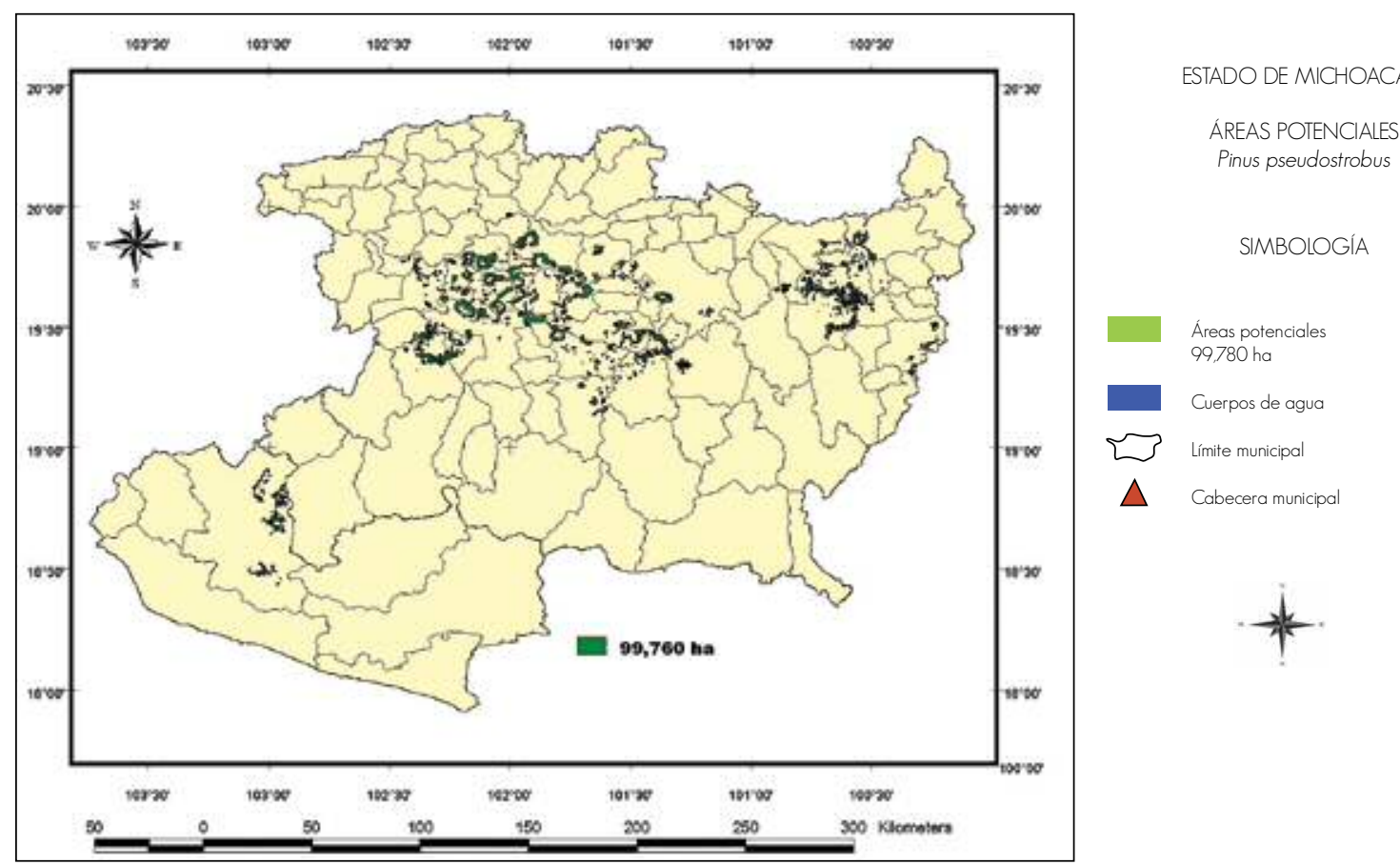

Figura 4. Áreas potenciales para el establecimiento de plantaciones forestales comerciales no mecanizadas de P. pseudostrobus Lindl., en Michoacán (pendiente 15-30\%).

Figure 4. Sites with potential for non-mechanized establishment of commercial forest plantations of Pinus pseudostrobus Lindl., in Michoacán (slopes $15 \%$ to $30 \%$ ).

Eguiluz (1978) señala que la distribución de P. pseudostrobus en México se extiende entre los paralelos $17^{\circ} 15^{\prime}$ a $29^{\circ} 15^{\prime}$ de latitud norte y los meridianos $92^{\circ} 05^{\prime}$ a $108^{\circ} 35^{\prime}$ de longitud oeste, en la Sierra Madre Oriental, el Eje Neovolcánico, la Sierra Madre del Sur, la Sierra Madre de Chiapas y parte de la Sierra Madre Occidental. Martínez (1948) y Perry (1991) lo registran en los estados de: Jalisco, Colima, Michoacán, Estado de México, Hidalgo, Distrito Federal, Guerrero, Morelos, Oaxaca, Coahuila, Chihuahua, Guanajuato, Chiapas, Puebla, Querétaro, Nuevo León, San Luís Potosí, Tamaulipas, Veracruz y Tlaxcala; en altitudes que varían de 1,600 a 2,400 m; en suelos profundos de 1 a 3 m, de color café amarillento, con pH de 4.5 a 7 , una capa de humus de 10 a $30 \mathrm{~cm}$ y alto contenido de nitrógeno, características del tipo Andosol.

Madrigal (1982), en Michoacán localiza la especie en las regiones Oriente, Suroccidente y Centro (Sierra Purhépecha); en altitudes de 2,200 hasta 3,000 m, en los municipios de Angangueo, Ciudad Hidalgo, Coalcomán, Los Reyes, Paracho, Uruapan, Nuevo San Juan Parangaricutiro, Tacámbaro, Tancítaro y Villa Madero. Los resultados del presente estudio coinciden ampliamente con dicho autor, ya que las áreas potenciales se ubicaron en los mismos municipios, excepto en Angangueo.

García (1996) afirma que en la Sierra Purhépecha la precipitación media anual es mayor de 1,500 mm, la temperatura media anual
A comparison between sites for Pinus pseudostrobus and P. greggii at 15 to $30 \%$ shows the latter sites with a larger coverage, which might indicate that this introduced species might adapt well to soil and climate conditions in Michoacán, even though $P$. greggii's growth and development should be monitored because of its susceptibility to pests and diseases.

Pinus greggii growns mainly in the mountains of Sierra Madre Oriental at elevations ranging from 1,300 to $3,000 \mathrm{~m}$ and from 2,000 to 3,100 m (depending of sources: Din, 1958; Eguiluz, 1978; Dvorak and Donahue, 1993; Ramírez et al., 2005).

Results in this research are consistent with Rueda (1998). This is an expected outcome because Rueda's screening criteria for 11 species considered for commercial forest plantations in Jalisco were nearly the same variables as this study in Michoacán. Software used was also the same, but in the current case a more recent version was available, thus Michoacán outputs should be more reliable.

\section{Results from field validation}

A total of 24 sites were visited in the field for both species. Pinus pseudostrobus was seen in 18 of these locations; however, ecological features suggest up to 22 of the 24 places have potential for growing that species. Only one site visited was 
es de $16.9^{\circ} \mathrm{C}$, estos datos son similares a los requerimientos ambientales considerados en la generación de los mapas.

\section{Áreas potenciales para Pinus greggii}

Se estimó una superfície de 253,623 ha con potencial para el establecimiento de (PFC) mecanizadas. La única región donde no se ubicaron fue en la IX (Figura 5 y Cuadro 4). deemed unsuitable, while 21 matched the designation of potential forecasted in this study.

Only two of the field plots had Pinus greggii present. Considering that $P$. greggii habitat is similar to $P$. pseudostrobus, in 17 of the field sites visited should be feasible to grow $P$. greggii. These 17 field plots include 14 sites that fall within areas declared suitable in this study.

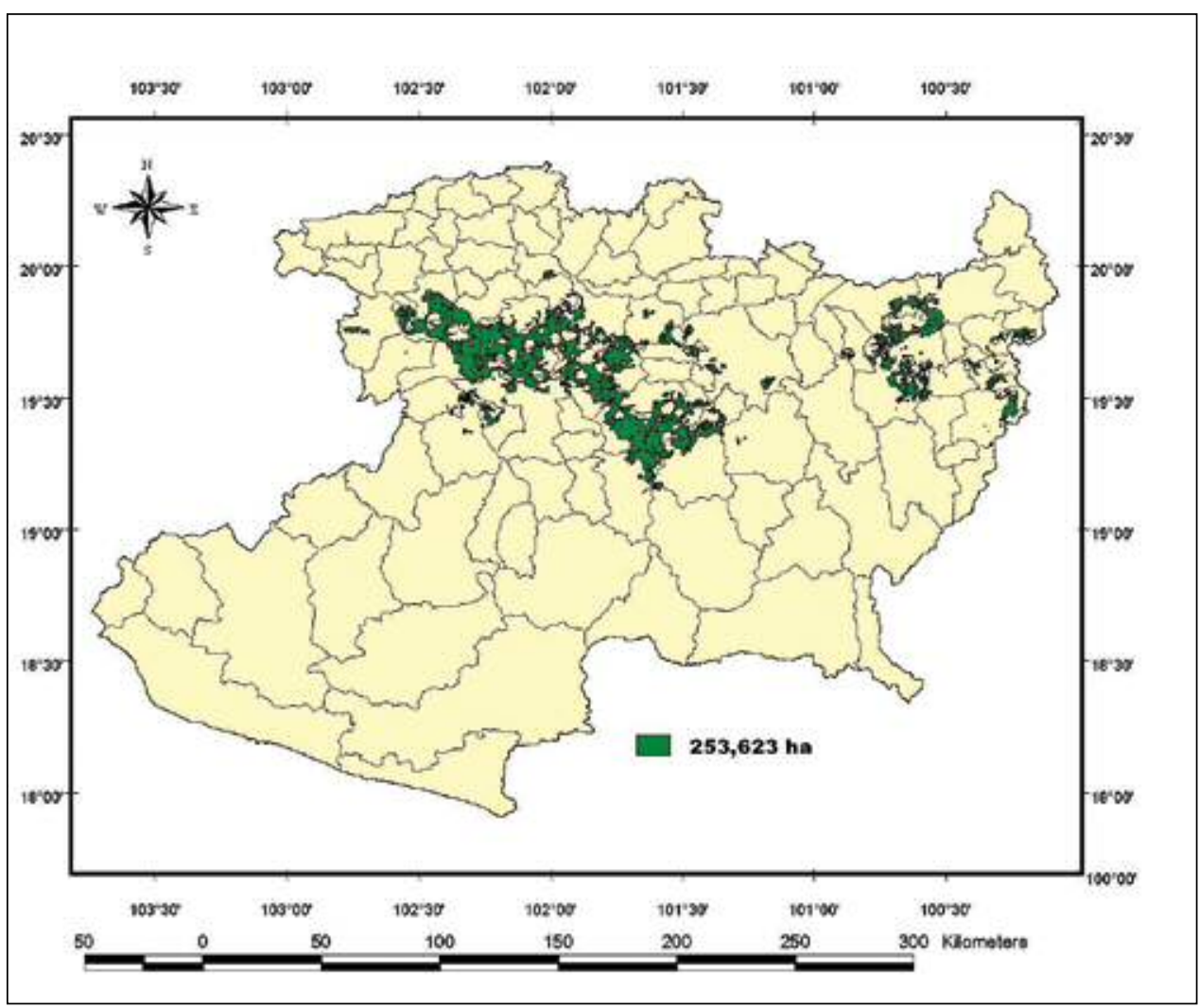

ESTADO DE MICHOACÁN

ÁREAS POTENCIALES

Pinus greggii

SIMBOLOG|A

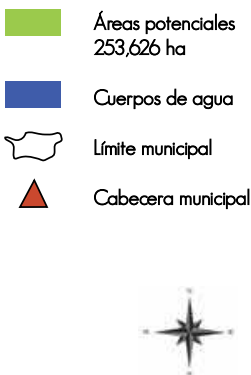

Figura 5. Áreas potenciales para el establecimiento de plantaciones forestales comerciales mecanizadas de P. greggii Engelm., en Michoacán (pendiente 0-15\%).

Figure 5. Areas with potential for mechanized establishment of commercial forest plantations of Pinus greggii Engelm., in Michoacán (slope $0 \%$ to $15 \%$ ).

Al igual que para $P$. pseudostrobus la mayor concentración de áreas potenciales se registró en la Meseta Tarasca, con una superficie ligeramente menor, seguida por la región Pátzcuaro-Zirahuén donde las áreas potenciales se presentaron en una extensión superior, a la estimada para P. pseudostrobus, con la misma pendiente (0- $15 \%$ ).

Para P. greggii con pendiente de $15-30 \%$ se definió una superficie potencial total de 108,365 ha. En las regiones Lerma-Chapala, Baiío, Cuitzeo, Oriente, Tepalcatepec, Meseta
This experience points out the need of a larger field validation sample to enhance confidence in the stated potential areas of this study. Additional validation is also required to prevent possible errors in the processing of information.

Granted, as Rueda (1998) requests, field validation of imagery handled with GIS is essential. Reygadas et al. (2000) adds the convenience of requesting expert opinion regarding forest plantations. 
Cuadro 4. Superficie potencial estimada (ha) para el establecimiento de plantaciones forestales comerciales de P. greggii Engelm., en Michoacán.

Table 4. Estimated potential area (ha) for establishing commercial forest plantations of Pinus greggii Engelm., in Michoacán.

\begin{tabular}{lcc}
\hline & \multicolumn{2}{c}{ Pendiente } \\
\cline { 2 - 3 } & $0-15 \%$ (ha) & $15-30 \%$ (ha) \\
\hline I. Lerma-Chapala & 14,260 & 5,239 \\
II. Baijo & 10,755 & 7,074 \\
III. Cuitzeo & 10,023 & 7,094 \\
IV. Oriente & 36,926 & 23,763 \\
V. Tepalcatepec & 29,007 & 8,149 \\
VI. Meseta Tarasca & 78,790 & 38,316 \\
VII. Pátzcuaro-Zirahuén & 53,913 & 13,978 \\
VII. Tierra caliente & 12,065 & 3,133 \\
IX. Costa & ---- & ---- \\
X. Infiernillo & 7,887 & 1,619 \\
Total & 253,626 & 108,365 \\
\hline
\end{tabular}

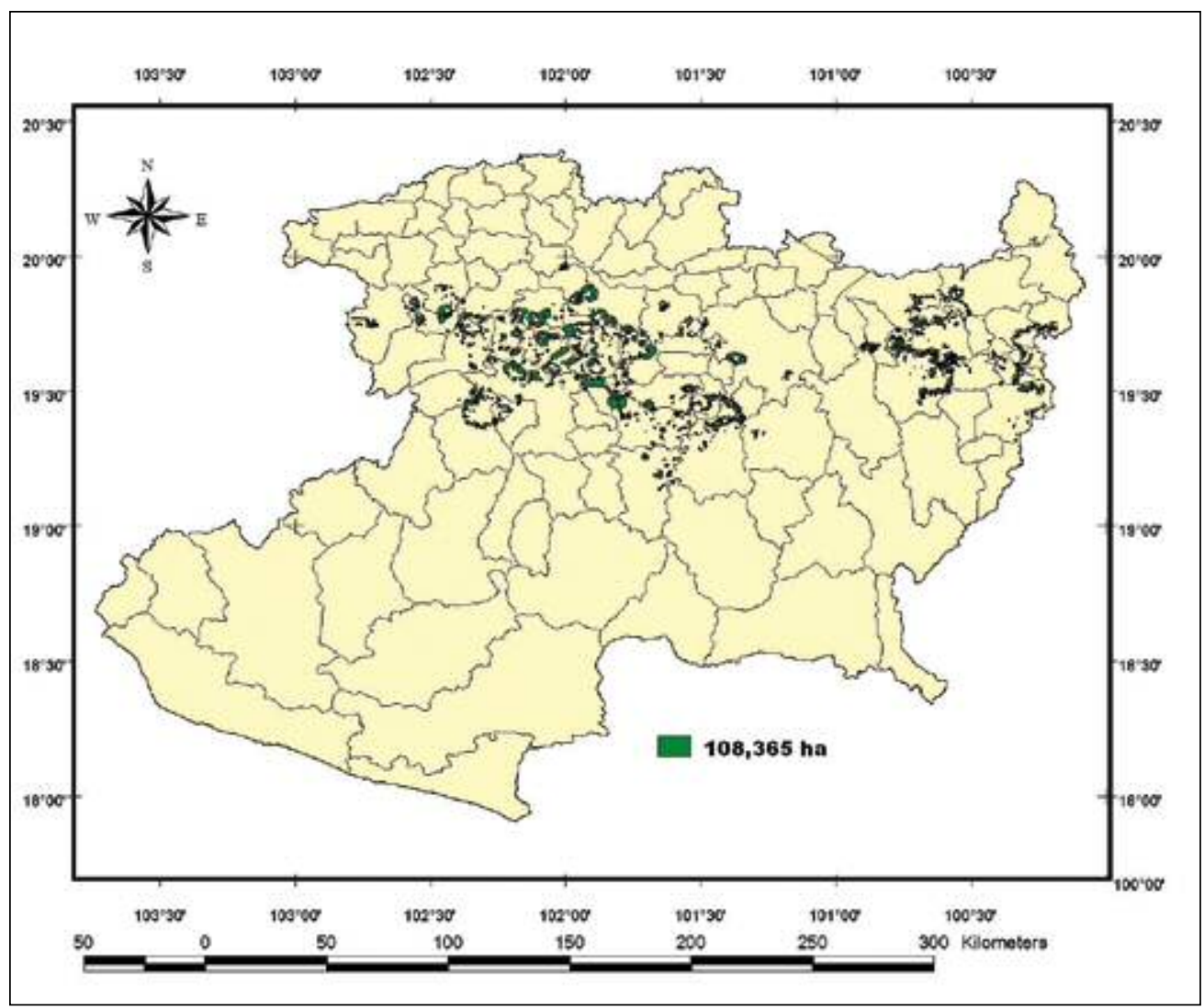

ESTADO DE MICHOACÁN

ÁREAS POTENAAIES

Pinus greggii

SIMBOLOGIA

Áreas potenclales $108385 \mathrm{ha}$

Guerpos de agua

$\simeq$ Limlte municipal

$\triangle$ Cabecera munlcipal

Figura 6. Áreas potenciales para el establecimiento de plantaciones forestales comerciales no mecanizadas de P. greggii Engelm., en Michoacán (pendiente 15-30\%).

Figure 6. Areas with potential for non-mechanized commercial forest plantations of Pinus greggii Engelm., in Michoacán (slope 15 to $30 \%$ ). 
Tarasca, Pátzcuaro-Zirahuén, Tierra caliente e Infiernillo se distribuyó en los mismos municipios, que se administraron para la pendiente de 0-15\%. La región Costa no se obtuvieron resultados favorables para plantaciones manuales (Cuadro 4 y Figura 6).

Al comparar la superficie obtenida con la pendiente de $15-30 \%$ para $P$. pseudostrobus y $P$. greggii s notable que a ésta última le correspondió una extensión mayor, lo que indica que a pesar de ser una especie introducida en la entidad, tendría buena adaptación en las condiciones edafo-climáticas de Michoacán, aunque se recomienda monitorear su desarrollo y crecimiento, ya que es susceptible al ataque de plagas y enfermedades.

P. greggii crece, principalmente, en las montañas de la Sierra Madre Oriental en altitudes de 1,300 a 3,000 m y de 2,000 a 3,100 m. Dicho intervalo varía de acuerdo a los autores (Din, 1958; Eguiluz, 1978; Dvorak y Donahue, 1993; Ramírez et al., 2005).

Los resultados que se consignan en este trabajo son similares a lo señalado por Rueda (1998), ya que las variables utilizadas para generar los mapas de áreas potenciales para plantaciones forestales de 11 especies de pino en Jalisco fueron prácticamente iguales a las que se consideraron para Michoacán. Además el SIG empleado fue el mismo, pero en versión más actualizada, lo que garantiza la confiabilidad de la información.

\section{Resultados obtenidos de la verificación en campo}

Se visitaron un total 24 sitios para ambas especies, en 18 de ellos se observaron individuos de P. pseudostrobus, pero con base en sus características ecológicas se considera que 22 tienen potencial para el desarrollo de esta especie, de los cuales 21 coincidieron con las áreas determinadas como potenciales y sólo uno quedó fuera de ésta.

P. greggii se presentó tan sólo en dos de los sitios verificados; sin embargo, debido a que sus requerimientos de hábitat son semejantes a los de $P$. pseudostrobus se presume que 17 son potenciales para su desarrollo; además coincidieron con las áreas potenciales definidas, excepto en tres puntos de verificación que se ubicaron fuera de ellos.

Por lo anterior es necesario incrementar las verificaciones de campo para comprobar si las condiciones de las áreas potenciales son las apropiadas para el desarrollo de las especies en estudio y corroborar que el programa no presente errores en la información generada.

Se concuerda con Rueda (1998), quien menciona que es indispensable realizar verificaciones en campo de la

\section{CONCLUSIONS}

Ecologic conditions in Michoacán are frequently favorable for successful establishment and development of commercial forest plantations of Pinus pseudostrobus and P. greggii.

Region VI Meseta contains the greatest area with potential for establishing $P$. pseudostrobus and $P$. greggii.

Numerous sites with 0 to $15 \%$ slope seem appropriate for $P$. pseudostrobus and $P$. greggii plantations, although this proposed forest use will compete with agricultural crops in these locations.

Geographic information systems (GIS) are dependable tools in assessing the potential sites for growing forest species.

In this research the number of validation sites placed were few; however, reported results are valid and trust worthy because most locations visited in the field showed favorable features for $P$. pseudostrobus and P. greggii successful development.

End of the English version 
información obtenida con el SIG. Por su parte Reygadas et al. (2000) señalan que además es conveniente llevar a cabo entrevistas con expertos en plantaciones forestales.

\section{CONCLUSIONES}

El estado de Michoacán, con base en sus características ecológicas, presenta condiciones favorables para el establecimiento y desarrollo de plantaciones forestales comerciales con $P$. pseudostrobus y $P$. greggii.

La región VI Meseta cuenta con la mayor superficie de áreas potenciales para el establecimiento de plantaciones forestales comerciales con $P$. pseudostrobus, y $P$. greggii.

A pesar del uso agrícola de los terrenos con pendiente de 0-15\% tienen condiciones aceptables para el establecimiento de plantaciones forestales comerciales con P. pseudostrobus yP. greggii.

Los Sistemas de Información Geográfica (SIG) son una herramienta confiable para determinar áreas potenciales para el establecimiento de especies forestales.

Los sitios de verificación en campo no fueron suficientes, sin embargo, la información generada es confiable, ya que en la mayoría de los lugares visitados se observaron condiciones favorables para el desarrollo de P. pseudostrobus y P. greggii.

\section{REFERENCIAS}

Carmona A., J. y J. J. Monsalve R. 1997. Sistemas de Información Geográficos. 24 p. Disponible: http://www.monografias.com/trabajos/gis/gis. shtml (30 de marzo de 2006).

Centro Agronómico de Tecnología, Investigación y Enseñanza (CATIE). 1997. Notas técnicas sobre manejo de semillas forestales Pinus pseudostrobus Lindl. No. 13. Turrialba, Costa Rica. 53 p.

Comisión Forestal del Estado de Michoacán (COFOM). 2003. Ecosistemas forestales de Michoacán. Revista Forestal XXI. Vol. 6(2): 7-10.

Comisión Nacional Forestal (CONAFOR). 2005. Se reduce el índice de la deforestación en México de acuerdo al más reciente estudio. Revista electrónica de la CONAFOR. "México Forestal". Bosques y selvas para siempre. No. 3. 2 p. http://www.mexicoforestal.gob. mx/nota.php?id=23 (20 de agosto de 2006).

Din V., A. 1958. Pinus para las regiones tropicales. UNASYIVA. Vol. 12 (3): 12- 13.

Dvorak W., S y K Donahue J. 1993. Reseña de las investigaciones de la Cooperativa CAMCPRE 1980-1992. Traducción en español por Jesús Meneses. Departamento Forestal del Colegio de Recursos Forestales Universidad Estatal de Carolina del Norte. Raleigh, NC. USA 94 p.

Eguiluz P., T. 1978. Ensayo de integración de los conocimientos sobre el género Pinus en México. Tesis Profesional. Departamento de Bosques. Escuela Nacional de Agricultura. Chapingo. Texcoco, Edo. de Méx. México. 614 p.

Food and Agriculture Organization of the United Nations/United Nations Education, Science and Culture Organization (FAO-UNESCO) (Eds.) (1975). Soil map of the world. Rome, Italy. 96 p.

García M J., J. 1996. Conferas promisorias para reforestación en la Sierra Purhépecha Agenda téanica No.2 NFAP. CRPAC. Uruapan, Mich México. 79 p.

González G. M J. 2002. Base de datos georreferenciados de las plantaciones subsidiadas por el PRODEPLAN mediante el uso de un sistema de información geogrática (SIG). Colegio de Posgraduados. México. hitp://www.conafor.gob.mx/programas nacionales forestales/imasd/ proyectos 2002/30.htm (30 de mayo de 2006).
Instituto Nacional de Estatística Geografia e Informática (INEGI). 1984. Cartas topográficas escala 1:500,000 del estado de Michoacán. Edición individual. México, D. F. México.

Instituto Nacional de Estatística Geografia e Informática (INEGI). 1985. Síntesis geográfica del estado de Michoacán. Instituto Nacional de Estadística Geografía e Informática. Secretaría de programación y presupuestos. México, D.F. México. 341 p.

Instituto Nacional de Investigaciones Forestales Agrícolas y Pecuarias (INFAP). 1993. Determinación del potencial productivo de especies vegetales en México: el estado de Jalisco. In: Memorias. VI Reunión Cientifica y Técnica Forestal y Agropecuaria. INFAP. Guadalajara, Jal. México. pp. 7-11.

León L, J. L 2005. Determinación de la superficie del bosque de pino-encino de la sierra de la laguna Centro de Investigaciones Biológicas del Noroeste (CIBNOR).México. Ip.http://www.conafor.gob.mx/programas nacionales forestales/imasd/Proyectos Investigacion/RFSO3..BCS.\%2O 0387.Luis\%2OLeon\%2OVVegetacion).doc (30 de marzo de 2006).

Madrigal S., X. 1982. Claves para la identificación de las coníferas silvestres del estado de Michoacán. INF. SARH. SFF. Boletín Divulgativo. No. 58. México, D.F. México. pp. 87-88.

Martínez, M. 1948. Los pinos mexicanos. Editorial Botas. $2^{\circ}$ edición. México. D. F. México. $361 \mathrm{p}$.

Moreno S., R y F. Moreno S. 1995. Los sistemas de información geogrática en la administración de recursos naturales: recomendaciones de las experiencias del INFAP. Rev. Cien. For. Méx Vol. 20(78): 93-109.

Organización de las Naciones Unidas para la Agricultura y la Alimentación (FAO). 1999. Sistemas de Información Geográfica para un desarrollo sostenible. Departamento de desarrollo sostenible. http://www. fao.org/sd/spdirect/gis/ElgisO00.htm (25 de junio de 2006).

Organización de las Naciones Unidas para la Agricultura y la almentación (FAO). 2000 Situación de la actividad forestal en México. Comisión Forestal para América del Norte 20` reunión. Nota informativa. Canadá 9 p. hitp:l/ www:ao.org/docrep/meeting/X4702S.htm (28 de julio de 2006).

Organización de las Naciones Unidas para la Agricultura y la Alimentación (FAO). 2005. La deforestación continúa a un ritmo alarmante. 7 p. http://www.fao.org/newsroom/es/news/2005/1000127/ index.html (25 de julio de 2006).

Ortiz S., C. A. 1987. Elementos de agrometorología cuantitativa con aplicaciones en la Republica Mexicana. Tercera edición. Chapingo, Edo. de Méx. México. 327 p.

Perry, J. P. 1991. The pines of Mexico and Central America. Timber press Inc Portland, OR. USA. 231p.

Pérez O. C. de la P, Olvera C. P. 1981. Anatomía de la madera de 16 especies de coniferas. SARH. INF. México. D.F. México. Boletín Técnico No. 69. $111 \mathrm{p}$

Ramírez H., C., J. J. Vargas H. y J. López U. 2005. Distribución y conservación de las poblaciones naturales de Pinus greggii. Acta Botánica Mexicana. No. 72: 1- 16.

Reygadas P., D., F. Sánchez M., R. Villareal C.y B. A. Silva T. 2000. Zonas potenciales para plantaciones forestales del área de Zitácuaro, Michoacán. In: Memorias del Primer Congreso Nacional de Reforestación. PRONARE-SEMARNAT. México, D.F. México. $11 \mathrm{p}$.

Rueda S., A. 1998. Áreas potenciales para plantaciones forestales de 11 especies de pino en Jalisco. Tesis de Maestría. Universidad de Guadalajara Guadalajara, Jal. México. 109 p.

Ruiz C., J. A. y A. Rueda S. 1994. Diagnóstico de áreas para la explotación de Abies religiosa en el estado de Jalisco. In: Memorias. VII Reunión Regional Cientififa y Técnica Forestal y Agropecuaria. CIPAC. INFAP. SARH. Guadalajara, Jal. México. 213 p.

Sáenz R., J. T., G. Chávez L., J. García M. y J. Anguiano C. 2000. Regionalización de áreas potenciales para plantaciones forestales en el oriente de Michoacán. In: Primer Congreso Nacional de Reforestación. PRONARE-SEMARNAT. México, D.F. México. 6 p.

Secretaría de Agricultura y Ganadería. Instituto Nacional de Investigaciones Forestales, Agrícolas y Pecuarias. SAGAR-INIFAP-Produce. 1997. Detección de áreas potenciales para la propagación del pinabete espinoso (Picea chihuahuana Mtz.). Tecnología llave en mano. INFAP-SAGAR. México, D.F. México. pp. 71-72. 